\title{
Effect of Planting Media and Iba Concentration on Rotting Ability of Stem Cutting Of Ligustrum ovalifolium.
}

\author{
Y. H. Hammo1, B. Z. Abdul Kareem2, M. I. Salih3 \\ 1(Hort. Dept., College of Agriculture and forestry/ Dohuk Univ., Iraq) \\ 2,3( Hort. Dept., College of Agriculture/ Salahalden Univ., Iraq)
}

\begin{abstract}
This study was carried out in the Agricultural College/ Salahalden University during the period between 1st March, 2010 to 1st August, 2010, to investigate the effect of planting media (sand, sand: loamy soil, and mixture of sand: loamy soil: peat moss) 1:1:1 by volume, and IBA concentrations (0, 1000, 2000, 3000) mg.l-1 on rooting ability of stem cuttings of Ligustrum ovalifolium. The results show that the mixture of sand, loamy soil, peat moss is significantly superior than other media and give the highest values of roots number 7.45 root/plant, roots dry weight $0.33 \mathrm{gm} /$ plant, shoot number 3.92 shoot/plant, leaf number 11.00 leaf/plant, and vegetative dry weight $3.76 \mathrm{gm} /$ plant while the best rooting percentage $64.63 \%$ is obtained in cutting which are planted in peat moss and the longest root is for cutting which are planted in sand media. The 2000 and 3000 mg.l-1 IBA causes significantly increase in rooting percentage $68.92,68.42 \%$, longest root $3.41,3.36 \mathrm{~cm}$, roots dry weight 0.31, 0.31 gm, leaf number 9.67, 9.56 leaf/plant when comported with the other concentration. In the other hand the $3000 \mathrm{mg} . \mathrm{l}-1$ is significantly superior in roots number 5.91 root/plant, shoots number 3.92 shoot/plant, and vegetative dry weight $2.82 \mathrm{gm} / \mathrm{plant}$.

The interaction between planting media and IBA concentrations case significantly variance in all rooting and shooting parameters and the highest values are for cutting treated with 2000, $3000 \mathrm{mg} . \mathrm{l}-1$ and planted in deferent media.
\end{abstract}

Keywords: Planting Media, IBA concentration, Ligustrum ovalifolium.

\section{Introduction}

Ligustrum is a genus of about $50 \mathrm{Semi}$ evergreen shrubs and trees from warm areas of Europe to Asia, the Plants are generally grown in warm temperate and subtropical climates (Whistler, 2000). The spices L. ovalifolium which belong to Oleaceae family reaches $15 \mathrm{ft}$; laves. Elliptic-ovate to elliptic-oblong, to $21 / 2 \mathrm{in}$. long, dark and glossy above, pale beneath; flowers nearly sessile, in panicles to 5 in. long, corolla 1.4 in. long, tube 1 1/2 times as long as spreading lobes, Fruits are 5-7 mm across, black (Bailey and Bailey, 1976; Batcher, 2000). It can reproduce by sexual (seeds) or vegetative means (root suckers, cuttings) (NRCS Plant Guide, 2002). Although the Glossy ligustrum may be difficult to root at times, the Softwood and spring hardwood cuttings of most ligustrums are root easily, it need about eight weeks for rooting (James, 2003). Vegetative propagation is used to maintain the genetic integrity of a plant and multiply it into a population of the same identical genotype without limit, ensuring those desirable characteristics that will be carried into the next generation (Ruchala, 2002; Hartmann et al., 2002).

Rotting hormones are very necessary for easy to root and difficult to root plants for its role in improve the quality of root system developed, decrease rooting time and improve the percentage of cutting rooted (salman, 1988). Also Hartmann et al., (2002) states that treating cuttings with Auxins increase the percentage of cutting that form roots, hastens root initiation and it is useful in propagating plants, and can increase production efficiency time from propagule to rooted liner. In contrast, too much rooting hormone can hinder root growth, so care has been taken to find the right concentration to use (Ruchala, 2002). Hammo et al., (2009) found that Increase IBA from 750 to $3000 \mathrm{mg} .1^{-1}$ concentration causes significantly increase in rooting percentage of shoot tip cutting of Myrtus communis when compared with other treatments, also increase this concentration from 2250 to $3750 \mathrm{mg} . \mathrm{l}^{-1}$ causes significantly increase in total roots length, roots dry weight and shoots number. Alsup and Cole, (2000) obtained that optimum rooting for Caddo Sugar Maple Acer saccharum was obtained with shoot tip cuttings taken at the green softwood stage and treated with $5000 \mathrm{mg} \cdot \mathrm{l}^{-1} \mathrm{IBA}$, and the average number of roots per cutting increased as IBA concentration increased also Root length was greatest with the $5000 \mathrm{mg} . \mathrm{l}^{-1}$ IBA treatment. It is important to choose the correct Rooting media to get optimum rooting in the shortest time; Peat moss is the most commonly used peat in horticulture (Hartmann et al., 2002). In addition, it attribute in improving the physical characteristics of the soil such as porosity and tissues soil and water holding capacity (Nyamangara, 2001). The main purpose of using organic amendments is to loosen the soil and create large pores to increase ( 1 aeration, 2 drainage, 3 usable water holding capacity, 4 nutrient holding capacity, 5 decrease growing media weight (compared to soil) (Reed, 2005). Hammo et al, (2009) found that Uses peat moss media cause significantly increased in all shoot tip cutting characters when compared with that propagate 
in sand and the increasing percentage reach $10.40 \%, 33.70 \%, 87.66 \%, 43.61 \%, 180.37 \%, 210.39,167.41$, and 140.71 for rooting percentage, total roots length, roots fresh weight, roots dry weight, shoots number, total shoots length, shoots fresh weight, and dry weight respectively. Because Ligustrum has long been cultivated in many areas of the world as hedge plants and as Small Street trees (Bailey and Bailey, 1976), the following study was undertaken to investigate the effects IBA application and media on the rooting of Ligustrum stem cuttings.

\section{Material and methods}

This study was carried out in the plastic house of Oz-has nursery Salahalden governorate from $15^{\text {th }}$ March, 2010 to $1^{\text {st }}$ July, 2010, to investigate the effect of planting media and IBA concentrations on rooting ability of stem cuttings of Ligustrum. Semi Hardwood cuttings, each $15 \pm 2 \mathrm{~cm}$ long of Ligustrum ovalifolium were planted in $15^{\text {th }}$ Mar, The $5 \mathrm{~cm}$ leaf basal portion of each cutting are removed and dipped in to $(0,1000$, $2000,3000) \mathrm{mg} . \mathrm{l}^{-1}$ concentrations of IBA solution to a depth of $2 \mathrm{~cm}$ (quick deep 5 second). Each five treated cuttings were cultivated into $780 \mathrm{~cm}^{3}$ polyethylene propagating container filled with three media (sand, sand: soil loamy, mixture of sand: loamy soil: peat moss (1:1:1 by volume). The experimental design was a randomized complete block design by using 5 cuttings for each one of the four replications. Thirteen weeks after the experiment was initiated, cuttings were harvested and data recorded include Rooting percentage, Mean number of roots/cutting, Mean length of longest root $(\mathrm{cm})$, Number of shoots/cutting, leaf number/cutting, dry weight of shoots per cutting (gm), Dry weight of roots (gm)/cutting. The statistical analysis and Means comparison was done by using Duncan's Multiple Ranges Test under 5\% (SAS, 2001).

\section{Results and Discussion}

1- Effect of planting media and IBA on rooting percentage, roots number, longest roots, and roots dry weight of Ligustrum ovalifolium cutting.

Data in table (1) show that the best media for rooting of the ligustrum stem cuttings are the peat moss which give the highest percentage $64.63 \%$, and sand $62.00 \%$ when compared with the sand: loamy soil $58.17 \%$ and sand: loamy soil: peat moss $51.21 \%$ and the increasing between all media are significantly. in the other side the sand media lead to increase the longest root $3.28 \mathrm{~cm}$ significantly when compared with the others media while the mixture of sand: loamy soil: peat moss give the highest means of roots number $4.75 \mathrm{root} / \mathrm{plant}$ and roots dry weight $0.33 \mathrm{gm} / \mathrm{plant}$ when compared with others media and the lowest means are for sand 3.58 root/plant and $0.21 \mathrm{gm} / \mathrm{plant}$ for the two characters respectively. The two high concentrations of IBA 2000 and $3000 \mathrm{mg} . \mathrm{l}^{-1}$ give the highest values with significant increase of rotting percentage $68.92 \%, 68.42 \%$, longest root $3.41,3.36 \mathrm{~cm}$, and roots dry weight $0.31,0.31 \mathrm{gm} /$ plant respectively when compared with the lowest concentration and control. Only the roots number increased significantly with gradual form 2.25, 3.33, 4.67, $5.91 \mathrm{roots} / \mathrm{plant}$ as the IBA increased from 0 to $3000 \mathrm{mg} \cdot \mathrm{l}^{-1}$ respectively. The interaction between media and IBA lead to significantly increased in all characters and the highest values of rooting percentage is $79.00 \%$ for cuttings that planted in peat moss and treated with $3000 \mathrm{mg} . \mathrm{l}^{-1}$ while the lowest value are $35.00 \%$ for all media except peat moss and $0 \mathrm{mg} .1^{-1}$. The highest roots number reach 6.47 root/plant and longest root $4.90 \mathrm{~cm}$ are for cutting that planted in peat moss and treated with $3000 \mathrm{mg} . \mathrm{l}^{-1}$ while the least value are $1.67 \mathrm{root} / \mathrm{plant}$ for controls plants that planted in peat moss. In the others side all cuttings which planted in mixture of sand: loamy soil: peat moss which treated in $1000,2000,3000 \mathrm{mg} \cdot \mathrm{l}^{-1}$ and $2000,3000 \mathrm{mg} \cdot \mathrm{l}^{-1}$ which planted in sand: loamy soil give the highest value which cannot differ significantly when compared each with other but it differ significantly than others interaction.

\section{2- Effect of planting media and IBA on shoot number, leaf number, and shoots dry weight, of Ligustrum ovalifolium cutting.}

The mixture of sand: loamy soil: peat moss give the best result in all vegetative characters as shown in table (2) with significantly increase than others media and the highest means reach 3.92 shoot/plant, 11.00 leaf/plant, $3.76 \mathrm{gm} / \mathrm{plant}$ for the shoot number, leaf number, and dry vegetative weight respectively.

In the other side the less values 1.67 shoot/plant, 4.13 leaf/plant, $0.98 \mathrm{gm} / \mathrm{plant}$ for these characters respectively are for sand media. IBA concentrations $3000 \mathrm{mg} \cdot \mathrm{l}^{-1}$ causes significantly increase in shoots number $3.92 \mathrm{shoot} /$ plant and vegetative dry weight $2.82 \mathrm{gm} / \mathrm{plant}$ than other treatment and the less number was for control which reach 1.92 shoot/plant, and $1.79 \mathrm{gm} /$ plant for the two characters respectively. While the 2000 mg. $1^{-1}$ gives the highest leaf number 9.67 leaf/plant. In contrast the less value is for control treatment which gives 5.13 leafs/plant. The interaction between planting media and IBA concentration case significantly deference in all vegetative parameters as shown in table (2), and the highest shoots number reach 4.67 shoot/plant for the cuttings which planted in sand: loamy soil and treated with $3000 \mathrm{mg} . \mathrm{l}^{-1}$, while the less value is 0.67 for cutting which planted in sand and treated with 0 mg..$^{-1}$ IBA. and the highest leaf number 14.44 shoot/plant and vegetative dry weight $4.80 \mathrm{gm} / \mathrm{plant}$ are obtained from cutting that planted in sand: loamy soil: peat moss and treated with 3000 mg. $\mathrm{l}^{-1}$ IBA, while the less value are for control cutting which planted in sand 
and it reaches 2.50 leaf/plant and $0.78 \mathrm{gm} / \mathrm{plant}$ for the two characters respectively.

Increased all characters except longest root for cutting which are planted in peat moss or the mixture which contain peat moss may be due to the increased in soil porosity and which leads to good ventilation, prevents accumulation of $\mathrm{CO}_{2}$ in the media as output of breathing roots and microorganisms in the soil, which leads to curb breathing and therefore growth, as well as the increase in granularity soil Granulation, with increased susceptibility center on water retention, and increase the capacity of ion exchange for the center (AlAni. 1980; Nelson, 1991). Or attributed to contain this media as quantities of adequate organic matter and their height ability to retain moisture, height porosity so as to facilitate the exchange of excess water and related the male Waters (Gilman, 1999; and Henley et al, 2002). This results are agree with Al-Atrakchi, (1996) which found that planted lilac cuttings in peat moss or mixture of peat moss with sand gave the highest rooting percentage, where as cuttings of lilac cvs. Monique lemione gave the highest rooting percentage when planted in river sand.

The significantly effect of IBA may be refer to its benefit as reported by Blazich (1988) and Hartmann et al. (2002) and role in the adventitious root produced so it will be hastening root initiation, increasing the number and quality of roots produced per cutting, and increasing the uniformity of rooting. Or to role of auxin in accumulate at the site of root formation and mobilizes sucrose or its derivative to the site of root formation and increased the total number of cuttings forming Greenwood and Berlyn (1973). This results are agree with Ucler et al., (2004) in their investigation on rooting ability of semi-hardwood Actinidia deliciosa cuttings found that treated cutting with IBA as quick-dip increased roots number and the rooting area. However, 6 and 8 g. $1^{-1}$ doses had similar effects on the rooting characteristics of cutting but significantly increased compared with control.

The increases in most of characters may be referring to the highly significant positive correlation between them as shown in table (3).

Table (1). Effect of planting media and IBA on rooting percentage and some root characters of Ligustrum ovalifolium cutting.

\begin{tabular}{|c|c|c|c|c|c|c|}
\hline \multirow{2}{*}{ 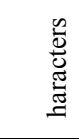 } & \multirow{2}{*}{ Media } & \multicolumn{4}{|c|}{ IBA concentration mg. $\mathrm{l}^{-1}$} & \multirow{2}{*}{$\begin{array}{l}\text { edia } \\
\text { ffect }\end{array}$} \\
\hline & & & 000 & 000 & 000 & \\
\hline \multirow{5}{*}{$\stackrel{\infty}{\underbrace{\infty}_{0}} a^{0}$} & Sand & $5.00^{\mathrm{e}}$ & $2.00^{\mathrm{b}}$ & $2.00^{\mathrm{b}}$ & $9.00^{\mathrm{b}}$ & $2.00^{\mathrm{b}}$ \\
\hline & peat moss & $3.50^{\mathrm{d}}$ & $4.00^{\mathrm{d}}$ & $2.00^{\mathrm{b}}$ & $9.00^{\mathrm{a}}$ & $4.63^{\mathrm{a}}$ \\
\hline & sand, loamy soil & $5.00^{\mathrm{e}}$ & $6.67^{\mathrm{cd}}$ & $2.00^{\mathrm{b}}$ & $9.00^{\mathrm{b}}$ & $8.17^{\mathrm{c}}$ \\
\hline & $\begin{array}{l}\text { sand, loamy soil, } \\
\text { peat moss }\end{array}$ & $5.00^{\mathrm{e}}$ & $3.50^{\mathrm{d}}$ & $9.67^{\mathrm{c}}$ & $6.67^{\mathrm{cd}}$ & $1.21^{\mathrm{d}}$ \\
\hline & IBA effect & $9.63^{\mathrm{c}}$ & $9.04^{\mathrm{b}}$ & $8.92^{\mathrm{a}}$ & $8.42^{\mathrm{a}}$ & \\
\hline \multirow{5}{*}{ 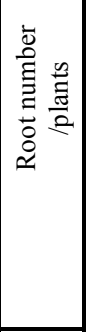 } & Sand & $.00^{\mathrm{de}}$ & $.33^{\mathrm{c}}$ & $.00^{\mathrm{c}}$ & $.00^{\mathrm{a}}$ & $.58^{\mathrm{b}}$ \\
\hline & peat moss & $.67^{\mathrm{e}}$ & $.67^{\mathrm{cd}}$ & $.33^{\mathrm{b}}$ & $.47^{\mathrm{a}}$ & $.78^{\mathrm{b}}$ \\
\hline & sand, loamy soil & $.00^{\mathrm{de}}$ & $.00^{\mathrm{c}}$ & $.67^{\mathrm{a}}$ & $.50^{\mathrm{a}}$ & $.04^{\mathrm{b}}$ \\
\hline & $\begin{array}{l}\text { sand, loamy soil, } \\
\text { peat moss }\end{array}$ & $.33^{\mathrm{c}}$ & $.33^{\mathrm{b}}$ & $.67^{\mathrm{a}}$ & $.67^{\mathrm{a}}$ & $.75^{\mathrm{a}}$ \\
\hline & IBA effect & $.25^{\mathrm{d}}$ & $.33^{\mathrm{c}}$ & $.67^{\mathrm{b}}$ & $.91^{\mathrm{a}}$ & \\
\hline \multirow{5}{*}{ 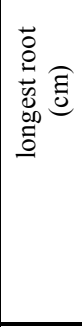 } & Sand & $.87^{\mathrm{e}-\mathrm{g}}$ & $.83^{\mathrm{b}}$ & $.83^{\mathrm{b}}$ & $.60^{\mathrm{ab}}$ & $.28^{\mathrm{a}}$ \\
\hline & peat moss & $.90^{\mathrm{e}-\mathrm{g}}$ & $.52^{\mathrm{g}}$ & $.63^{\mathrm{ab}}$ & $.90^{\mathrm{a}}$ & $.74^{\mathrm{b}}$ \\
\hline & sand, loamy soil & $.93^{\mathrm{e}-\mathrm{g}}$ & $.67^{\mathrm{de}}$ & $.50^{\mathrm{c}}$ & $.60^{\mathrm{d}-\mathrm{f}}$ & $.68^{\mathrm{c}}$ \\
\hline & $\begin{array}{l}\text { sand, loamy soil, } \\
\text { peat moss }\end{array}$ & $.77^{\mathrm{fg}}$ & $.57^{\mathrm{g}}$ & $.67^{\mathrm{c}}$ & $.33^{\mathrm{cd}}$ & $.58^{\mathrm{c}}$ \\
\hline & IBA effect & $.87^{\mathrm{c}}$ & $.65^{\mathrm{b}}$ & $.41^{\mathrm{a}}$ & $.36^{\mathrm{a}}$ & \\
\hline \multirow{4}{*}{ 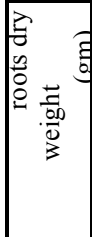 } & Sand & $.20^{\mathrm{ef}}$ & $.20^{\mathrm{ef}}$ & $.20^{\mathrm{ef}}$ & $.23^{\mathrm{ef}}$ & $.21^{\mathrm{d}}$ \\
\hline & peat moss & $.21^{\mathrm{ef}}$ & $.22^{\mathrm{ef}}$ & $.31^{\mathrm{b}-\mathrm{d}}$ & $.25^{\mathrm{de}}$ & $.25^{\mathrm{c}}$ \\
\hline & sand, loamy soil & $.18^{\mathrm{f}}$ & $.30^{\mathrm{cd}}$ & $.35^{\mathrm{a}-\mathrm{c}}$ & $.36^{\mathrm{a}-\mathrm{c}}$ & $.30^{\mathrm{b}}$ \\
\hline & sand, loamy soil, & & & & & \\
\hline
\end{tabular}




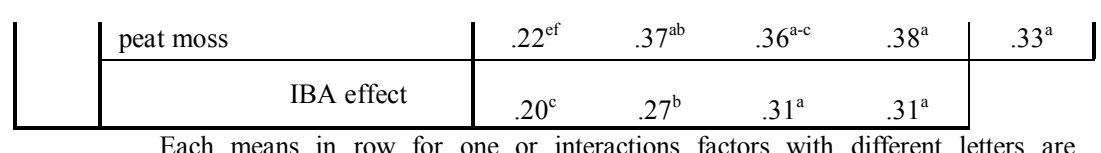

Each means in row for one or interactions factors with different letters are significantly different at $\mathrm{P}=0.05$ using Duncan's multiple range test.

Table (2). Effect of planting media and IBA on some vegetative characters of Ligustr ovalifolium cutting.

\begin{tabular}{|c|c|c|c|c|c|c|c|}
\hline \multirow{2}{*}{ 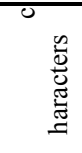 } & \multirow{2}{*}{ Media } & \multicolumn{4}{|c|}{ IBA concentration mg. $1^{-1}$} & \multirow{2}{*}{$\begin{array}{l}\text { edia } \\
\text { ffect }\end{array}$} & \multirow{2}{*}{$\begin{array}{l}\mathrm{M} \\
\mathrm{e}\end{array}$} \\
\hline & & & 000 & 000 & 000 & & \\
\hline \multirow{5}{*}{ 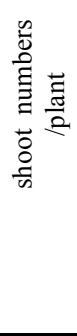 } & Sand & $.00^{\mathrm{ef}}$ & $.67^{\mathrm{f}}$ & $.67^{\mathrm{d}-\mathrm{f}}$ & $.33^{\mathrm{a}-\mathrm{d}}$ & $.67^{\mathrm{c}}$ & 1 \\
\hline & peat moss & $.33^{\mathrm{b}-\mathrm{f}}$ & $.67^{\mathrm{a}-\mathrm{f}}$ & $.33^{\mathrm{a}-\mathrm{d}}$ & $.33^{\mathrm{a}-\mathrm{d}}$ & $.92^{\mathrm{b}}$ & 2 \\
\hline & sand, loamy soil & $.33^{\mathrm{d}-\mathrm{f}}$ & $.00^{\mathrm{c}-\mathrm{f}}$ & $.17^{\mathrm{c}-\mathrm{f}}$ & $.67^{\mathrm{a}}$ & $.54^{\mathrm{bc}}$ & 2 \\
\hline & sand, loamy soil, peat & $.00^{\mathrm{a}-\mathrm{e}}$ & $.00^{\mathrm{a}-\mathrm{c}}$ & $.33^{\mathrm{ab}}$ & $.33^{\mathrm{ab}}$ & $.92^{\mathrm{a}}$ & 3 \\
\hline & IBA effect & $.92^{\mathrm{c}}$ & $.33^{\mathrm{bc}}$ & $.88^{\mathrm{b}}$ & $.92^{\mathrm{a}}$ & & \\
\hline \multirow{5}{*}{ 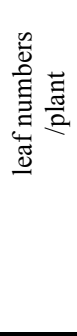 } & Sand & $.50^{\mathrm{h}}$ & $.00^{\mathrm{gh}}$ & $.67^{\mathrm{fg}}$ & $.33^{\mathrm{ef}}$ & $.13^{\mathrm{d}}$ & 4 \\
\hline & peat moss & $.00^{\mathrm{ef}}$ & $.33^{\mathrm{de}}$ & $.68^{\mathrm{c}}$ & $.25^{\mathrm{cd}}$ & $.82^{\mathrm{c}}$ & 1 \\
\hline & sand, loamy soil & $.67^{\mathrm{fg}}$ & $.00^{\mathrm{cd}}$ & $2.00^{\mathrm{b}}$ & $.33^{\mathrm{c}}$ & $.75^{\mathrm{b}}$ & 8 \\
\hline & sand, loamy soil, peat & $.33^{\mathrm{de}}$ & $0.00^{\mathrm{c}}$ & $2.33^{\mathrm{b}}$ & $4.33^{\mathrm{a}}$ & $1.00^{\mathrm{a}}$ & 1 \\
\hline & IBA effect & $.13^{\mathrm{c}}$ & $.33^{\mathrm{b}}$ & $.67^{\mathrm{a}}$ & $.56^{\mathrm{a}}$ & & \\
\hline \multirow{5}{*}{ 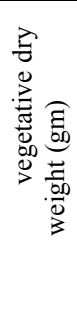 } & Sand & \multirow{2}{*}{$\begin{array}{l}.78^{\mathrm{g}} \\
.88^{\mathrm{ef}}\end{array}$} & $.99^{\mathrm{g}}$ & $.91^{\mathrm{g}}$ & $.23^{\mathrm{g}}$ & $.98^{\mathrm{c}}$ & 0 \\
\hline & peat moss & & $.26^{\mathrm{d}-\mathrm{f}}$ & $.44^{\mathrm{d}-\mathrm{f}}$ & $.34^{\mathrm{d}-\mathrm{f}}$ & $.23^{\mathrm{b}}$ & 2 \\
\hline & sand, loamy soil & $.85^{\mathrm{f}}$ & $.90^{\mathrm{ef}}$ & $.49^{\mathrm{de}}$ & $.89^{\mathrm{cd}}$ & $.28^{\mathrm{b}}$ & 2 \\
\hline & sand, loamy soil, peat & $.66^{\mathrm{d}}$ & $.39^{\mathrm{c}}$ & $.20^{\mathrm{b}}$ & $.80^{\mathrm{a}}$ & $.76^{\mathrm{a}}$ & 3 \\
\hline & IBA effect & $.79^{d}$ & $.14^{\mathrm{c}}$ & $.51^{\mathrm{b}}$ & $.82^{\mathrm{a}}$ & & \\
\hline
\end{tabular}

Each means in row for one or interactions factors with different letters are significantly different at $\mathrm{P}=0.05$ using Duncan's multiple range test.

Table (3). The correlation coefficients between all characters.

\begin{tabular}{|c|c|c|c|c|c|c|}
\hline Characters & $\begin{array}{l}\text { ooting } \\
\%\end{array}$ & $\begin{array}{c}\text { oots } \\
\text { number }\end{array}$ & $\begin{array}{l}\text { ongest } \\
\text { roots }\end{array}$ & $\begin{array}{c}\text { R } \\
\text { oots dry } \\
\text { weight }\end{array}$ & $\begin{array}{l}\text { hoots } \\
\text { number }\end{array}$ & $\begin{array}{c}\text { eaf } \\
\text { number }\end{array}$ \\
\hline Roots number & $.61 * *$ & & & & & \\
\hline longest roots & $.76 * *$ & $53 * *$ & & & & \\
\hline $\begin{array}{lll}\text { Roots } & \text { dry } \\
\text { weight } & & \\
\end{array}$ & .28 & $.57 * *$ & 0.17 & & & \\
\hline shoots number & .24 & $.64 * *$ & .04 & $.79 * *$ & & \\
\hline Leaf number & 0.02 & $.49 * *$ & 0.17 & $.74 * *$ & $.85^{* *}$ & \\
\hline $\begin{array}{lll}\text { weight } & & \text { dry } \\
\end{array}$ & .18 & $.56^{* *}$ & .01 & $.49^{* *}$ & $.62 * *$ & $.62 * *$ \\
\hline
\end{tabular}




\section{References}

[1]. Al- Atrakchii, A. O. (1996). Studies on vegetative propagation in Syringa, Spartium and Callistemon. Ph.D. Thesis, College of Agriculture and Forestry, Mosul University. (In Arabic)

[2]. Al-Ani, A. N. (1980). Principles of soil science. Library Foundation for printing and publishing, the University of Mosul.

[3]. Alsup. C. M. and J. C. Cole.(2000). Effect of Timing and IBA on Rooting of Caddo Sugar Maple Acer saccharum Stem Tip Cuttings SNA Research onference - Vol. 45: 324-327.

[4]. Bailey, L.H. and E.Z. Bailey. (1976). Hortus. 3rd ed. Macmillan General Reference, NY.

[5]. Batcher, M.S. (2000). Element Stewardship Abstract for Ligustrum spp. The Nature Conservancy's Wildland Invasive Species Team, University of California, Davis, CA.

[6]. Blazich, F. A. (1988). Mineral Nutrition and Adventitious Rooting. In: Davis, T. D., B. E. Haissig and N. Sankhla N, (eds.). Adventitious Root Formation in Cuttings. Dioscoides Press, Portland, Ore. pp. 61-69.

[7]. Gilman, E. F. (1999). Nephrolepis exaltata. Cooperative Extension Service Institute of Food and Agricultural Science, Univ. of Florida fact Sheet FPS 427.

[8]. Hammo, Y. H., Mayi A. A. T., and Sadeeq J. A. (2009). Effect of Media and Indole Butyric Acid on Shoot Tip Cutting of Myrtus communis L. J. Duhok Unvi. 12 (2) 2009.

[9]. Hartmann, H. T., D. E. Kester, F. T. Davis, Jr., and R. L. Geneve (2002). Hartmann and Kester's Plant Propagation: Principles and Practices. $7^{\text {th }}$ ed. Prentice Hall, Upper Saddle Loamy, N.J.

[10]. Henely, R. W., L. S. Osbornee and A. R. Chase (2002). Boston fern production. Guide. University of Florida, IFAS file://A: fern.7.htm.

[11]. James T. Midcap, Robert J. Black, Sylvester A. Rose 2003 ENH-45, a series of the Environmental Horticulture Department, Florida Cooperative Extension Service, Institute of Food and Agricultural Sciences, University of Florida. at http://edis.ifas.ufl.edu.

[12]. Nelson, P.V. (1991). Greenhouse operation and management ( $4^{\text {th }}$ Ed.). Prentice. Hall. Inc. N.J.USA (C.F. Al-Shoura and Hosn (1996). Annals Agric. Sci., 41(2): 973-991).

[13]. NRCS Plant Guide. 2002. Exotic Weed Species: Chinese privet, Ligustrum sinense Lour. USDA, NRCS National Plant Data Center, Louisiana.

[14]. Nyamangara, J., J. Gotosa., and S. E. Mpofu (2001). Cattle manure effects on structural stability and water retention capacity of a granitic sandy soil in Zimbabwe. Soil and Tillage Research. 62: 157-162.

[15]. Reed. D.W. (2005). Soil Composition and Necessary Amendments. General Horticulture laboratory Manual, 2nd ed. Burgess Publ., Edina, Mn) Texas A\&M University .1-12.

[16]. Ruchala, S. L. (2002).Propagation of several native ornamental plants. M.Sc. Thesis, Univ. of Maine.

[17]. Salman, M.A. (1988).Horticulture Plants Propagation .Daralkotob publishing and pressing, Mosul Univ., Iraq.(In Arabic)

[18]. SAS. (1996).Statistical Analysis System. SAS Institute Inc., Cary, Nc. USA.

[19]. Ucler, A. O., S. Parlak and Z. Yucesan (2004). Effects of IBA and cutting dates on the rooting ability of semi-hardwood kiwifruit Actinidia deliciosa A. chev. cuttings. Turk. J. Agric For 28:195-210.

[20]. Whistler, W.A. 2000. Tropical Ornamenatals. Timber Press, Portland, OR.

[21]. Greenwood, M. S. and G. P. Berlyn (1973). Sucrose indole-3-acetic acid interactions on root regeneration by Pinus lambertiana embryo cutting. Amer. J. Bot. 60(1): 42-47. 